\title{
Biogas production plants; existing classifications and proposed categories
}

Emma Lindkvist and Magnus Karlsson

The self-archived postprint version of this journal article is available at Linköping University Institutional Repository (DiVA):

http:// urn.kb.se/ resolve?urn=urn:nbn:se:liu:diva-145451

N.B.: When citing this work, cite the original publication.

Lindkvist, E., Karlsson, M., (2018), Biogas production plants; existing classifications and proposed categories, J ournal of Cleaner Production, 174, 1588-1597.

https:// doi.org/ 10.1016/j.jclepro.2017.10.317

Original publication available at:

https:// doi.org/ 10.1016/j.jclepro.2017.10.317

Copyright: Elsevier

http:// www.elsevier.com/

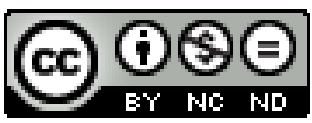




\title{
Biogas production plants; existing classifications and proposed categories
}

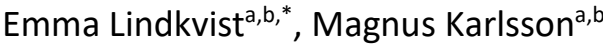 \\ aDepartment of Management and Engineering, Division of Energy Systems, Linköping University, SE-581 83 Linköping, \\ Sweden \\ ${ }^{\mathrm{b} B i o g a s}$ Research Center, Linköping University, Sweden \\ *Corresponding author: aDepartment of Management and Engineering, Division of Energy Systems, Linköping University, \\ SE-581 83 Linköping, Sweden. Email address: emma.lindkvist@liu.se
}

\begin{abstract}
Production of biogas from anaerobic digestion has the potential to be part of the transition to a renewable based energy system. However, diverse classifications may obstruct knowledge sharing within and between countries, thus potentially hindering development of biogas solutions, as part of an environmentally sustainable renewable based energy system. The aim of this study is to present an approach to categorize biogas production plants and to investigate and compare some countryspecific classifications of biogas production plants. The study shows that there are differences between the country-specific classifications studied, both in the terminology and in the underlying descriptions when the terminology is the same. It is also shown that the biogas plants studied do not fit into all of the in-depth country specific European classifications studied. A Framework for Categorization that includes seven categories is proposed. When the biogas plants studied are inserted into the framework, similarities between different plants are shown. These similarities are not found when using the existing European biogas plant classifications. It has also been shown that only three of the proposed categories are included in any of the four in-depth European classifications studied. The Framework, developed in this study, shows the complexity of common categories for biogas production plants, and it is an attempt towards finding a common classification for biogas plants.
\end{abstract}

Keywords: Biogas, Anaerobic Digestion, Classification, Categorization, Framework 


\section{Introduction}

The European Commission (2010) has launched the 2020 climate and energy package, a set of binding legislations. The package is set to ensure that the European Union (EU) meets the energy and climate targets for 2020, including the $20 \%$ target on increased share of renewable sources, where biogas may play a part in reaching the target. In addition, increased biogas production has obvious effects on reaching the target of reducing greenhouse gas (GHG) emissions by $20 \%$ (European Commission, 2010). An increased role for biogas in the $\mathrm{EU}$ is also manifested in its communication "Renewable Energy Road Map" (European Commission, 2007), by indicating an increase of biogas used for electricity production until 2020. The European Commission has extended the targets to a $40 \%$ reduction of GHG emissions by 2030 , relative to the levels in 1990, and at least a $27 \%$ share of renewables by 2030 (European Commission, 2014).

The Renewable Energy directive (RES directive) (European Commission, 2009) states that biogas installations can contribute significantly to sustainable development, and the directive settles the $10 \%$ target for renewables within the transport sector. It emphasizes that each country has to propose relevant measures to reach a balanced use of domestic and imported renewables for transportation considering, amongst other concerns, the issue of security of energy supply.

Increased use of energy from renewable sources is not only promoted to reduce GHG emissions and to increase security of energy supply, but it also provides opportunities for labor and regional development according to the RES directive (European Commission, 2009). Additionally, technology development and innovation are promoted in the directive, and the potential to establish economic growth through innovation has been documented. Exchange of best practices is encouraged regarding production of electricity, heat or biofuels for transportation, and the RES directive states that "... the European Institute of Innovation and Technology should give high priority to the research and development of renewable energy technologies"(European Commission, 2009).

To increase biogas production, both within EU and globally, the complexity of biogas solutions has to be handled; for example, biogas solutions include different substrates and different applications for both the biogas produced and the digestate. The ambition of the EU is significant regarding renewable energy, including an increase of biogas production. This stresses the importance of knowledge sharing to promote innovations regarding biogas production in the EU that in turn create new industries, new jobs, and local and regional development. A comparison between different biogas solutions is vital, to be able to identify new ideas and innovations as well as for knowledge sharing. However, the comparison must be able to handle the complexity of biogas solutions. Diverse classifications may obstruct knowledge sharing within and between countries, thus potentially hindering development of biogas solutions. To the knowledge of the authors of this paper, no previous research on classification of biogas production plants have been performed.

The aim of this paper is to present an approach to categorize biogas production plants and to investigate and compare country-specific classifications of biogas production plants.

\section{Method}

Databases have been searched to find similar studies. The databases used are, among others, Google scholar, Scopus and Web of science. The search words used were biogas classification, biogas 
categorization, biogas definition, biogas comparison and biogas division. The results from the literature search shows that no similar study has been performed previously.

To achieve the aim of the paper, the work was accomplished by (i) sorting different types of biogas plants into country-specific European classifications, (ii) proposing categories to be used when categorizing biogas plants, (iii) sorting different types of biogas plants into the proposed categories as well as, (iv) investigating how the country-specific European classifications are covered in the proposed categories. The work has been carried out by using literature studies, organizing one workshop, formulating a framework, and carrying out assessments in accordance to Figure 1.

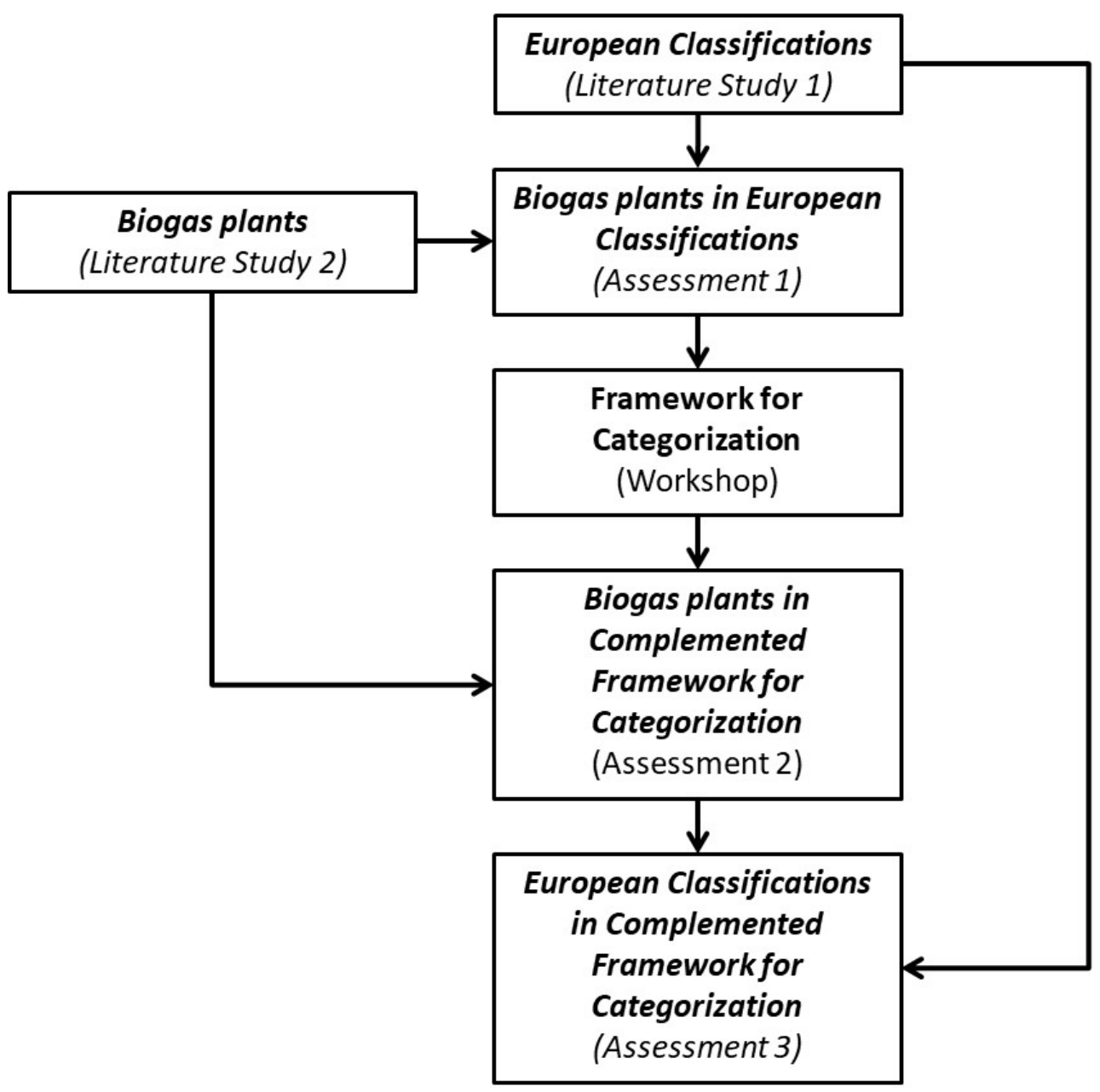

Figure 1. Working process in the study.

Information regarding country-specific European classifications was searched for using literature studies to find relevant and well-documented classifications (Literature Study 1). Literature studies were also carried out to find information regarding existing Swedish biogas plants (Literature Study 2). In the latter literature study, the intention was to find different types of plants and both Internetbased information (homepages of companies operating biogas plants) and documents to gather information. This was complemented with some additional questions to some companies. These literature studies were carried out during 2014.

The literature studies were then used to find out how different types of biogas plants are sorted in some existing European classifications (Assessment 1) to find differences and similarities between the 
classifications. When carrying out Assessment 1, not only the denominations of the different European classifications were used from Literature Study 1 as input, but also the underlying explanations of the classifications.

Literature Study 1 was used as the basis for the workshop that was arranged in February 2014. The European classifications were not shown to the attendants until after the workshop in order to avoid any preconception. The participants during the workshop totaled 8 persons, experts in the field of biogas, ranging from academic experts on digestion, systems analysis, energy, and environmental issues. In the complementary work after the workshop, some strategic persons within companies in the biogas field were also consulted on the issue.

Brainstorming was used as the main method during the workshop. Prathibha Varkey et al. (2009) state that brainstorming is used to expose a range of perspectives in developing numerous possible solutions. According to Summers and White (1976), brainstorming consists of typically 6-12 persons, and it is recommended that the participants have different backgrounds. Prathibha Varkey et al. (2009) also state that the participants should be familiar with the problem.

According to (Prathibha Varkey et al., 2009) a well-defined problem formulation is vital for carrying out a creative brainstorming. During the workshop, the problem was formulated as to identify possible categories when characterizing biogas plants and also to prioritize between the generated categories. The workshop was arranged in subsequent steps. The workshop started with a brainstorming session where the participants pictured the biogas system together. The purpose of the task was to picture the actors, components, relations, cooperation, and complexity in the production of biogas. The motive for the arrangement of this step was to involve all participants to contribute with their experience and know-how to get a comprehensive picture of biogas systems. The next step was carried out as another brainstorming session with the overall question at task: what comprehensive categories are found in the process description from the preceding step that may be important in a definition of biogas plants, and what is not found in the process description?

To avoid giving any of the participants an interpretation prerogative, each participant was first given the opportunity to include their own ideas using note paper. This is also underlined by Summers and White (1976), as they state that during a brainstorming session it is important to avoid judgment of ideas and encourage numerous ideas. Summers and White (1976) and Prathibha Varkey et al. (2009) emphasize that using ideas from other participants to create new ideas is vital in brainstorming. This was promoted when all the initial ideas where presented for the participants during the workshop. In the last step of the workshop, the most essential categories were highlighted. The purpose of this step was to remove marginal categories to reduce the number of categories and stress the most essential ones. This step was arranged by giving each participant the opportunity to mark five essential categories of their own choice. The motive for this approach was to give all participants the opportunity to mark any of the proposed categories. The categories with most marks were then used to produce the Framework for Categorization, as noted at the workshop in Figure 1.

The biogas plants studied (Literature Study 2) were thereafter sorted into the proposed categories in the Framework for Categorization (Assessment 2). During the workshop, some subcategories were formed to clarify and emphasize the diversity of the different categories. When including the biogas plants studied, supplementary subcategories were merged into the Framework for Categorization, resulting in the Complemented Framework for Categorization. The reason for Assessment 2 was to 
establish the usefulness of the proposed categories and find out patterns between the biogas plants studied.

Finally, the existing European classifications (Literature Study 1) were sorted into the proposed categories in the Complemented Framework for Categorization (Assessment 3). The reason for Assessment 3 was to establish the possible overlapping between the existing classifications and the proposed categories.

\section{Results and Analysis}

\subsection{European classifications - Literature Study 1}

European classifications for different biogas plants were studied based on information from the European member countries in International Energy Agency (IEA) Bioenergy Task 37. The main focus in Task 37, which was started in 2010, is biogas production and utilization, as well as the economic and environmental sustainability of biogas (IEA Bioenergy Task 37, 2014). In Table 1, the classification of biogas plants of the European member countries in IEA Task 37 is found. The four countries with a description of the classifications are found to the left in the table in alphabetical order. The descriptions of the classifications are presented below. The countries without a description of the classifications are presented in the right-hand side of the table in alphabetical order. The classifications are organized in a similar way in Table 1.

\subsubsection{Denmark}

In Denmark, the classification of biogas plants consists of two subclasses: centralized biogas plants and farm biogas plants. According to the Danish biogas association, a centralized biogas plant receives manure from several farms and other forms of organic residues; in other words, they receive organic waste from industry and households, as well as biomass in the form of plant material. The biogas produced is used in Combined Heat and Power (CHP) plants, where it replaces natural gas (Brancheforeningen for Biogas, 2014a). The farm biogas plants are only treating manure from a particular farm and maybe a neighboring farm. Industrial organic waste can be treated as well, in order to increase gas production. The gas produced mainly goes to generate electricity on the farm. The electricity is sold to the grid and the heat is used at the farm (Brancheforeningen for Biogas, 2014b).

\subsubsection{Sweden}

In Sweden, the classification of biogas plants consists of five subclasses (Paulsson and Steinwig, 2013):

(i) Co-digestion, (ii) Farm-scale, (iii) Industrial, (iv) Landfills, and (v) Wastewater Treatment Plants (WWTP).

Co-digestion plant implies biogas production plants that receive collected organic material such as Municipal Solid Waste (MSW), slaughterhouse waste, manure, and energy crops, for example, but not sewage sludge. In Farm-scale biogas plants, mainly manure and other organic material from the farm are digested. Industrial plants also digest on-site residues. The classification Landfill includes landfills, which extract and utilize landfill gas. WWTP primarily digest sewage sludge (Paulsson and Steinwig, 2013). 


\subsubsection{Switzerland}

The classification of biogas plants in Switzerland consists of five subclasses (Kaufmann, 2013): (i) Agriculture, (ii) Commercial/Industrial (iii) Industrial Wastewater, (iv) Landfill, and (v) WWTP.

Agriculture plants mainly use manure, and the biogas is primary used at the farm. Commercial/Industrial biogas plants implies biogas plants that are operated with MSW and industrial waste, while Industrial Wastewater implies biogas plants that treat Industrial Wastewater only. In the classification Landfill, only landfills that utilize the collected landfill gas are included. WWTPs are municipal sewage treatment facilities (Kaufmann, 2013).

\subsubsection{United Kingdom}

In the United Kingdom, there are four subclasses for biogas plants in the classification (NNFCC, 2014): (i) Agricultural, (ii) Community, (iii) Industrial, and (iv) Water Industry AD Plant.

Agricultural indicates an anaerobic digester which uses residues produced exclusively on-farm; for example, they are taken from manure, crops or crop residues. Community plants implies plants that mainly use food waste collected from multiple sources, while Industrial plant implies plants which uses residues from the site. The term Water Industry AD Plant means that it is a WWTP including anaerobic digestion (NNFCC, 2014).

\subsubsection{Analysis}

Even if the classifications used by the four countries presented in Sections 3.1.1 to 3.1.4 have very similar terminology in some cases, the descriptions of the classifications differ; see, for example, the description for Agriculture plants in Switzerland and the UK. The authors of this paper have not found descriptions of classifications, for some of the countries introduced in Table 1. Therefore, it is not possible to use these classifications in any further analysis in this paper, because each classification may comprise different descriptions. For example, as shown in Table 1, three countries use the classification "Agriculture," but this classification may have different underlying meanings in the different countries.

The European Biogas Association are presenting the number of biogas plants in Europe by feedstock type in their statistical report from 2016 (Stambasky et al., 2016). The different feedstock types are; Agriculture, Sewage, Landfill and Other. In connection with the database search, a number of papers were found that uses some of the classifications mentioned in the above sections, without clarifying the underlying descriptions of the classification. For example, Bohn et al. (2007) uses the terms centralized plants, on-farm and farm-scale, whilst Igliński et al. (2015), Weiland (2006), GonzálezGarcía et al. (2013) and Karlsson et al. (2017) use the term agricultural plants. Huttunen et al. (2014) use the term co-digestion, whilst Holm-Nielsen et al. (2009) have an intention to clarify different classifications of agriculture plants in a European context. However, the clarification tends to be based on the Danish classification (Centralized and Farm scale biogas plants).

\subsection{Biogas plants - Literature Study 2}

For this study, ten biogas plants were chosen to be able to test the Complemented Framework for Categorization, and to analyze the European classifications. The plants were chosen to get as wide a picture of biogas production as possible. Swedish biogas plants, with distinctive characteristics, were used in this study to test the framework and analyze the classifications. 
In Sweden, biogas was produced at 233 plants in 2011 (Paulsson and Steinwig, 2013). The biogas plants are mainly located in the southern parts of Sweden and along the coast in the northern parts of the country. The plants studied are marked on the map in Figure 2, and described in the sections below. The plants studied differ in various ways, for example by location, substrate used, digestion technologies, organization, biogas use, digestate use, and capacity.

The Swedish Gas Association has divided the Swedish biogas production plants into five subclasses: Co-digestion Plants, Farm-scale Plants, Industrial Plants, Landfills, and WWTP, as described in Section 3.1.2. According to the Swedish Gas Association, the plants studied are classified as below (Energigas Sverige, 2013):

- Co-digestion Plants: Laholm (3), Linköping (4), and Västerås (9)

- Farm-scale Plants: Bjuv (1), Luleå (5), and Malmö (6)

- Industrial Plants: Umeå (7) and Örnsköldsvik (10)

- Landfill: Helsingborg (2)

- WWTP: Uppsala (8) 


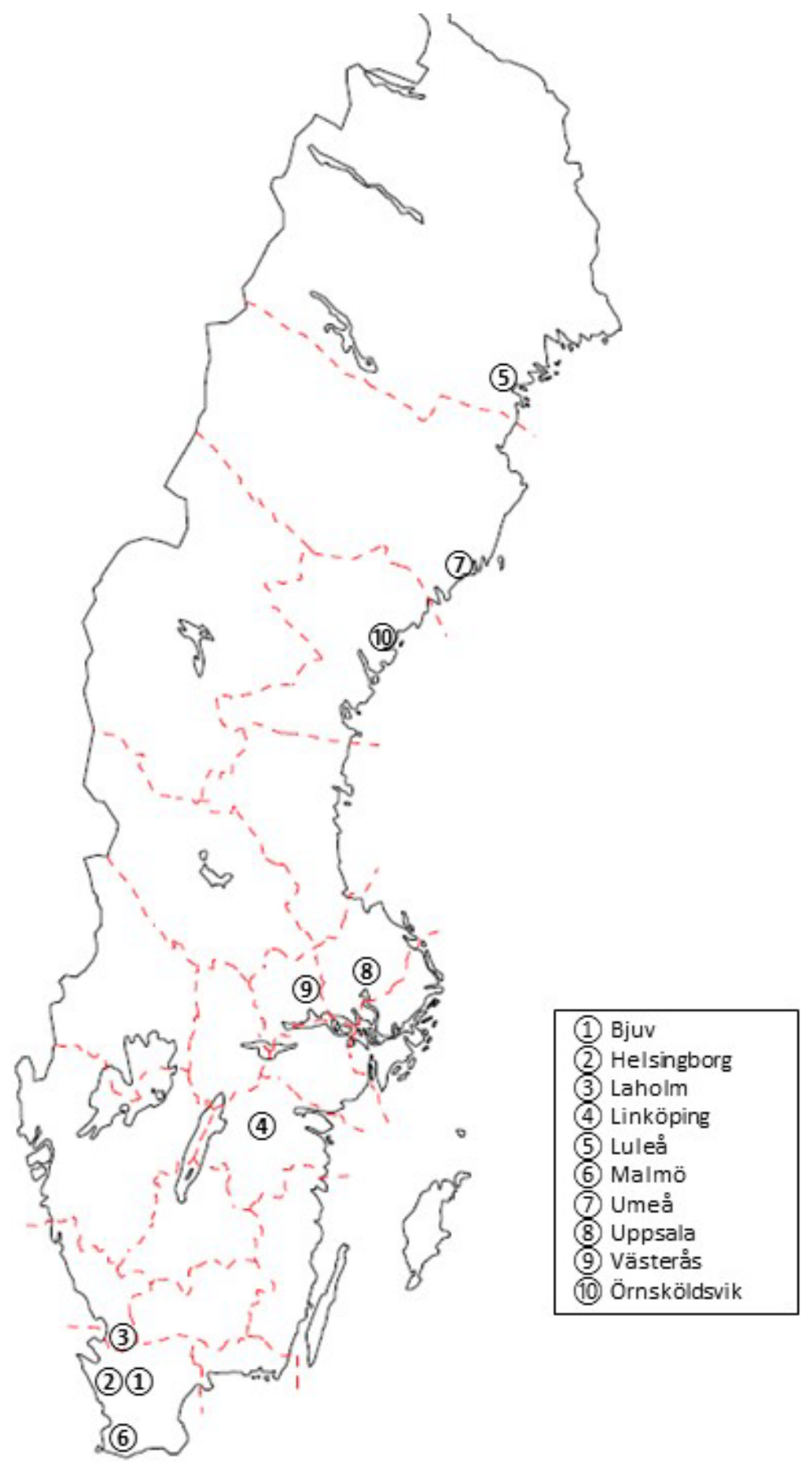

Figure 2. The plants studied. CC BY Lantmäteriet

\subsubsection{Bjuv}

The biogas plant in Bjuv is located on a farm (Naturvårdsverket, 2012). The ownership is divided between three owners who together constitute the company Söderåsens Bioenergi $A B$. The substrates digested at the plant are pig manure from the farm $(7,000 \mathrm{t} / \mathrm{a})$, organic waste from a food processing industry $2 \mathrm{~km}$ from the plant $(30,000 \mathrm{t} / \mathrm{a})$, and slaughterhouse waste $(6,500 \mathrm{t} / \mathrm{a})$. The waste from the food processing industry is pumped to the plant through specialized delivery pipes (Söderåsens Bioenergi, 2017). The biogas plant produces $30 \mathrm{GWh} / \mathrm{a}$ in one digester $\left(4,200 \mathrm{~m}^{2}\right)$ (Naturvårdsverket, 2012). The process operates at $38^{\circ} \mathrm{C}$ and the biogas is sold to an energy company, which upgrades it 
to natural gas quality and injects it into the national gas grid. The upgrading is done at the farm. The digestate is stored at the farm in storage tanks from which it is pumped through above-ground pipelines to the fields (Naturvårdsverket, 2012). The digestate is certified according to Swedish standard (SP, 2014).

\subsubsection{Helsingborg}

In Helsingborg, landfill gas is collected at a landfill. The landfill is managed by a municipal company owned by six municipalities. The main waste in the landfill is MSW, but since 2005, landfilling of organic waste has been forbidden in Sweden (Avfall Sverige, 2014), and therefore no new materials are added to it. The collected landfill gas is delivered to a thermal power station, connected to a district heating system. The total energy extracted from the landfill gas is 35-40 GWh/a (NSR, 2014).

\subsubsection{Laholm}

In Laholm, the biogas plant is managed by a commercial company (Södra Hallands Kraft, 2014a). The biogas is produced from manure and organic waste from slaughterhouses and other industries (Södra Hallands Kraft, 2014b) in two digesters of 2,250 $\mathrm{m}^{3}$ (Södra Hallands Kraft, 2014c). The process operates at $38^{\circ} \mathrm{C}$ and the biogas produced is upgraded and then injected into the natural gas grid. The gas is transported to the upgrading site, which is owned by an energy company, through pipelines (Södra Hallands Kraft, 2014c). The digestate is certified according to Swedish standards (SP, 2014).

\subsubsection{Linköping}

In Linköping, biogas is produced by a municipal company, mainly from slaughterhouse waste and MSW (Naturvårdsverket, 2012). The substrates are digested in four digesters with a total volume of 17,400 $\mathrm{m}^{3}$ and the process is carried out at $38^{\circ} \mathrm{C}$. The biogas is upgraded to vehicle fuel and distributed to filling stations trough a local gas grid or transported by vehicle to areas without biogas production. The total annual production of upgraded biogas is $100 \mathrm{GWh}$ (Naturvårdsverket, 2012). The digestate is certified according to Swedish standard (SP, 2014) and delivered to surrounding farmland.

\subsubsection{Luleå}

Outside of Luleå, biogas is produced at a farm from internal slaughterhouse waste and pig manure, as well as from external slaughterhouse waste (Naturvårdsverket, 2012). The substrates are digested at $55^{\circ} \mathrm{C}$ in two digesters $\left(1,000\right.$ and $\left.1,300 \mathrm{~m}^{3}\right)$. Water vapor and sulfur are removed from the biogas, and the water vapor is transferred to an accumulation tank, which provides hot water for the farm. The biogas is used to generate electricity $(4,300 \mathrm{MWh} / \mathrm{a})$, which is sold on to an energy company. However, $60 \%$ of the electricity is bought back to cover the electricity demand at the farm. The digestate is used on the farm's own fields (Naturvårdsverket, 2012).

\subsubsection{Malmö}

The biogas plant outside of Malmö is located on a crop production farm (Naturvårdsverket, 2012). The biogas plant receives chicken manure (100 t/a) as well as food industry waste $(700 \mathrm{t} / \mathrm{a})$. The digestion is performed at $37^{\circ} \mathrm{C}$ in one digester $\left(450 \mathrm{~m}^{3}\right)$. In total, 2,000 MWh of biogas are produced per year. Electricity $(650 \mathrm{MWh} / \mathrm{a})$ and heat $(200 \mathrm{MWh} / \mathrm{a})$ are produced from the biogas. The heat is used at the farm and at a neighboring farm. $10 \%$ of the generated electricity is used at the farm and the other part sold on to the grid. The digestate is stored and used at the farm (Naturvårdsverket, 2012). 


\subsubsection{Umeå}

In Umeå, biogas is produced at a dairy factory from whey, milk residue, and process wastewater from the factory, as well as from whey from another dairy factory (Naturvårdsverket, 2012). The biogas plant is a cooperation between the dairy factory and several research institutions in Sweden. The biogas is used in a steam boiler at the dairy factory, and the annual production of biogas is $22 \mathrm{GWh}$. The substrates used are digested in two digesters with a total volume of $5,000 \mathrm{~m}^{3}$, at $36^{\circ} \mathrm{C}$. The digestate is used as nutrient improvement in cultivation of reed canary grass (Naturvårdsverket, 2012).

\subsubsection{Uppsala}

In Uppsala, biogas is produced from wastewater by a municipally owned company (Uppsala Vatten, 2013). The process is performed at $37^{\circ} \mathrm{C}$ in two digesters of $3,000 \mathrm{~m}^{3}$ each. The biogas produced is used for production of heat and electricity (46\%), as well as upgraded to vehicle fuel (25\%). The rest is flared (Uppsala Vatten, 2013). The digestate is certified according to Swedish standard (SP, 2014).

\subsubsection{Västerås}

In Västerås, MSW is digested in the biogas plant together with ley crop silage and sludge from fat separators (Naturvårdsverket, 2012). The biogas plant is operated by a municipally owned company, and the process is performed at $37^{\circ} \mathrm{C}$ in one digester of $4,000 \mathrm{~m}^{3}$. The biogas produced is upgraded to vehicle fuel, and transported to filling stations in Västerås through pipelines. The annual biogas production is $15.4 \mathrm{GWh}$. The digestate is separated into two parts, one solid part, which is used as soil improvement, and one liquefied, which is used as nutrient improvement for the farmlands (Naturvårdsverket, 2012).

\subsubsection{0 Örnsköldsvik}

The biogas plant in Örnsköldsvik is part of a biorefinery where cellulose for textiles, bioethanol, and lignin, for example, are also produced. Two chemical industries in the area contribute financially to the biogas plant (Naturvårdsverket, 2012). Annually, about 2,000,000 $\mathrm{m}^{3}$ of wastewater from the three industries are treated at the plant. Biogas is produced in two digesters with a total volume of $30,000 \mathrm{~m}^{3}$, at a temperature of $37^{\circ} \mathrm{C}$. In total, $80 \mathrm{GWh}$ of biogas are produced per year, which is either used internally or sold on to an energy company, where it is used in a CHP plant. The digestate is used as soil improvement (Naturvårdsverket, 2012).

\subsection{Biogas plants in European classifications - Assessment 1}

In Assessment 1, the biogas plants studied (Literature Study 2) have been inserted into the European classifications (Literature Study 1), as seen in Table 2. The plants have been inserted into the classifications based on the underlying descriptions of the subclasses in the classifications together with the specific data for the plant. In Table 2, each column represents one classification, and each cell represents a subclass for that classification.

In the Danish classification, biogas use is specified, which has the effect that only two of the Swedish plants can possibly be included. None of the Swedish plants studied align with the description of a centralized plant, since none receive manure from several farms and then use the biogas produced in CHP plants.

The result for Sweden in Table 2 does not correspond completely with the classification made by the Swedish Gas Association found in section 3.2. In Table 2, only one plant is found in the subclass Farm- 
scale, whereas in section 3.2, there are three plants in this subclass. In Table 2, the other two plants are regarded as co-digestion plants, since they do not mainly digest waste from the proprietary farm (Bjuv (1)), or sometimes not at all (Malmö (6)). The plants regarded as industrial in section 3.2, are in Table 2 also found in the subclass WWTP, since sludge from wastewater is also digested in the plants. Hence, the plants are found in two different subclasses.

Three plants do not fit into the Swiss classification of biogas plants, Bjuv (1), Västerås (9) and Laholm (3). The plant in Bjuv (1) digests manure and industrial waste, but no MSW, and the biogas produced is not utilized at the farm. In Laholm (3), manure and industrial waste are digested at the plant, and in Västerås the plant digests MSW and ensilaged ley. The plant in Umeå (7) also does not totally fit into the classification, since Industrial Wastewater is digested together with industrial waste.

In the UK classification, none of the plants studied correspond to the subclass Agriculture, since all plants located on farms also receive substrate from other sources than the farm in focus. Hence, they are regarded as Community plants instead.

The biogas plants in Luleå (5) and Malmö (6) are found in the classification for all countries studied, as well as in the same subclasses, except in the Swedish one, where Luleå (5) is regarded as farm-scale and Malmö (6) as co-digestion. It is also these two plants that are the only ones that fit into the Danish classification. Bjuv (1), Laholm (3), and Västerås (9) do not fit into the Swiss classification, while all plants are found in the classifications from Sweden and the UK.

\subsection{Framework for Categorization - Workshop}

During the workshop, 17 different categories in total were found to characterize a biogas plant. From these 17, seven were selected, as they were considered the most essential categories, according to the participants at the workshop. The seven categories are Substrate, Organization, Biogas Use, Digestion Technology, Localization, Digestate, and Capacity, and they are ranked with a decreasing importance, based on the outcome of the workshop. These categories form the Framework for Categorization. Subcategories have been added to the Framework for Categorization to distinguish the differences between the biogas plants studied, thus forming the Complemented Framework for Categorization, as seen in Table 3. Each column in Table 3 represents a category, and each cell represents a subcategory for that category. The subcategories originate from the specific input data from the biogas plants studied, and are therefore plant specific. Other types of plants might add subcategories to some of the categories to the Complemented Framework for Categorization.

The category "Capacity" indicates the size of the digesters at the biogas plants. The fragmentation is based upon data from the biogas plants studied and has been made by the authors to have a distinction between the sizes of biogas plants. The subcategory "Commercial" means that the biogas plant is operated by a company, which does not own the substrate from the beginning, nor is it a municipal company. Moreover, the subcategory "Substrate Pumped" relates to substrate that is being pumped from the source to the biogas plant. If the biogas produced is used at the site in some way, it is indicated by the subcategory "Internal Use." The subcategory "Energy Conversion for External Use" means that the biogas produced is converted to, for example, heat and/or electricity and to some extent used externally. 


\subsection{Biogas plants in Complemented Framework for Categorization - Assessment 2}

As stated in the previous section, the Complemented Framework for Categorization was formed by adding subcategories to the Framework for Categorization. In Assessment 2 , the biogas plants studied, presented in 3.2, were inserted into the Complemented Framework for Categorization, as seen in Table 4.

It is important to note that the division in Table 4 is not representative enough to draw extensive conclusions on the amount of the different plants in the different subcategories because the plants included have been, as stated earlier, included to represent different types of plants. However, it may be noticed that the following categories are well represented (more than half of the plants):

- Substrate - industrial waste

- Digestion Technology - mesophilic

- Localization - close to main substrate

- Localization - substrate transported by vehicle

- Capacity-middle

As can be seen in Table 4, biogas use differs between the plants studied. At the plants in Luleå (5), Malmö (6), Uppsala (8) and Örnsköldsvik (10), the biogas is used for more than one purpose (of which one is electricity).

There are similarities between Bjuv (1) and Laholm (3); they have the same substrate, biogas use, technology, digestate use, and capacity. However, there are some differences in the category localization and organization. For example, the plant in Bjuv has a shared ownership while the plant in Laholm is owned by a commercial company. Also, the main substrate in Bjuv are found on-site, while in Laholm, the substrate is solely transported by vehicle.

All plants among the ones studied that upgrade the biogas produced into vehicle fuel are owned by a municipality. For the plants owned by substrate owners, the biogas is used internally and to produce electricity and in one case to produce heat.

\subsection{European classifications in Complemented Framework for Categorization - Assessment 3}

In Assessment 3, the European classifications presented in Section 3.1, were incorporated into the Complemented Framework for Categorization, as presented in Section 3.4, and seen in Table 5. The aim was to establish which categories are of importance in the classifications.

As seen in Table 5, only three of the categories (Substrate, Biogas Use, and Localization) are used in the country-specific classifications, and the rest of the categories (Organization, Digestion Technology, Digestate, and Capacity) are not incorporated into any of the classifications studied.

In the Danish and Swiss classifications, use of biogas is mentioned, while none of the other classifications studied mentions this category in the descriptions of the classifications. The kind of substrates used are specified for all the classifications studied, and the classification for UK also takes into account the localization of the substrates in relation to the biogas plants. 


\section{Discussion}

The disposition for this chapter follows the working process as presented in Figure 1, and finally an overall discussion regarding the implications of the existing classifications and the proposed Framework for Categorization.

When studying classifications of biogas plants from different countries (Literature Study 1), it is clear that there are ambiguities in the terminology between countries. However, even when the terminology corresponds between country classifications, the description of the subclasses may still differ. If scientists use the existing classifications, without clearly defining them, it might cause problems in understanding research results, and knowledge sharing between scientists from different countries may be obstructed. Including more country classifications into this study would not change the ambiguities found in Literature Study 1.

Information about ten different Swedish plants was gathered (Literature Study 2). The plants were not selected to provide a representative picture of the biogas production in Sweden, but rather to test how the Framework for Categorization and how the existing classifications in different countries performs for different kinds of biogas plants. The ten Swedish plants may not be representative in a global perspective, and perhaps not even in a Swedish perspective. However, these ten Swedish plants confirm the purpose of showing ambiguities in current classifications, and exemplifying the performance of the proposed Framework for Categorization.

As can be seen in Table 2 where the biogas plants studied are inserted into the European classifications studied (Assessment 1), only two of the biogas plants could be inserted into the Danish classification. This could be due to the underlying descriptions of the subclasses in the Danish classifications being detailed and adapted to specific Danish conditions in biogas production, and hence, not applicable to the plants studied. The plants studied can all be included in the Swedish and UK classifications, even if they differ in terminology. For example, the plant in Helsingborg (2) is classified as a Landfill in Sweden, but as a Community plant in the UK classification because the main waste on the landfill is MSW. The aim of Assessment 1 was to investigate how different biogas plants are sorted within some of the existing European classifications for biogas plants. If more biogas plants or if biogas plants from other countries would have been studied, it still would not affect the conclusions from Assessment 1 , since it is already shown that the studied classifications do not cover all of the biogas plants studied.

The categories used in the Framework for Categorization are supposed to open up possibilities for other approaches when classifying biogas plants. The categories are well grounded, but do not have the ambition to be comprehensive. The aim with the Framework is to show the complexity of common categories for biogas production plants and it is an attempt towards finding a common classification for biogas plants.

The subcategories are included in the Framework for Categorization to describe the ten biogas plants studied. If other plants are studied, subcategories may be added or replaced with others. The purpose of the subcategories is to show differences between the plants studied, but not to study patterns in general. However, comparisons between the plants studied in this paper can be done. As can be seen in Table 4, there are some similarities between different plants as, for example, the plant in Bjuv (1) and the plant in Laholm (3). The biogas plant in Bjuv is classified as a Farm-scale plant in the Swedish classification, and the plant in Laholm as a Co-digestion plant. However, according to Table 2 in section 
3.3, both plants are classified as Co-digestion plants. These similarities might be overlooked due to the misinterpretation of the Swedish classification descriptions. Hence, important knowledge that may be drawn from the two plants may be disregarded. Moreover, the landfill in Helsingborg can be included in three out of four of the European classifications studied and in four out of seven categories in the Complemented Framework for Categorization. The other three categories are not applicable to landfills (digestion technique, digestate, and capacity). Landfills have another purpose outside of producing biogas or handling a substrate, which may be the reason for the problems of including it in the country classifications and the challenges of including it in the Framework for Categorization.

In Assessment 2, the aim was to explore how different types of biogas plants are sorted in the Complemented Framework for Categorization. If more biogas plants would have been studied, it would probably result in more subcategories, other patterns, and more biogas plants in the existing subcategories. However, using the ten Swedish plants is enough to exemplify the performance of the proposed Framework for Categorization.

In Assessment 3, the aim was to investigate how some existing classifications are covered by the proposed categories. As shown in Table 5, Denmark is represented more frequently in the categories than the other countries studied. This may indicate that the underlying description of the subclasses in the Danish classification is more detailed than in classifications from the other countries studied. As has been discussed before, the level of details results in only two of the studied Swedish biogas plants being able to be inserted into the Danish classifications.

As can be seen in Table 5, only three of the proposed categories are included in any of the European classifications studied. One reason for this could be that classifications have been developed in different ways, and there could be differences between what academics, biogas organizations and the biogas industry find important. Moreover, biogas production in different countries has developed differently and with specific purposes (e.g., taking care of municipal waste and handling manure); therefore, the origins and uses of biogas differ. This could also be an explanation as to why classifications of biogas plants differ between countries.

The study shows the ambiguities in existing classifications, as not all of the studied classifications can handle all the different plants presented in this study. In fact, some of the classifications are not even firmly grounded within each country, including the Swedish classification, as shown when different biogas plants are sorted within some existing European classifications (Assessment 1). This is a problem when trying to compare plants and when trying to draw conclusions about different aspects within a certain subclass. This may also be a problem for technology transfer and mutual learning between different plants, and between and within countries experiencing similar problems and possibilities. By extension, this may hinder innovations. This also creates ambiguities within the EU when discussing different plants, as the basis for different plants are not firm. With prolongation of the current system, it may make different policy instruments very problematic to implement, as different types of plants may need different kinds of policy instruments to support e.g. environmental sustainability.

The study also shows the complexity of common categories. Different categories may be important for different actors (e.g., EU, state, biogas producers, investors, and academia). Looking at the results, substrate is the main foundation for the different European classifications. This may be explained by the history of biogas production, e.g. as a way to use residuals as substrates or even to eliminate a 
waste problem. The aim of this study is not to propose a new classification, but to show the complexity of mutual categories. Yet, the Framework for Categorization may be a base for such work. Another example of approach is to assume biogas to be the main purpose in biogas production, as opposed to, for example, a waste management instrument, and then an analogy of CHP from the energy sector may be used. In this sector, the raw material is not visualized in the concept CHP. Instead, plants using biofuel when producing electricity and heat are sometimes called biofuelled CHP.

\section{Conclusion}

It has been shown that the country classifications studied do not cover all the biogas plants studied, and there are differences between the studied classifications, both in the subclasses, and in the underlying descriptions of them. A Framework for Categorization is proposed, including seven categories: Substrate, Organization, Biogas Use, Digestion Technology, Localization, Digestate, and Capacity. When the biogas plants studied are inserted into the Framework, similarities between different plants are shown. These similarities are not found when using the existing European classifications of biogas plants. It has also been shown that only three of the proposed categories (Substrate, Biogas Use, and Localization) are included in any of the four European classifications studied, and only the Danish classification is represented in these three categories. Sweden, Switzerland, and the UK only cover Substrate and Localization.

The ten studied Swedish plants adequately exemplifies the performance of the proposed Framework for Categorization. However, to gain a representative picture of biogas production in Sweden, and in Europe, more biogas plants have to be added into the Framework for Categorization.

Biogas has the potential to be part of the transition from a non-renewable based energy system to an environmental sustainable renewable based energy system. However, a diverse terminology may obstruct knowledge sharing within and between countries, and thus hinder development toward a renewable based energy system. Therefore, the effect of using different country classifications on results in technology transfer and policy instruments, for example, needs to be studied.

The Framework, developed in this study, shows the complexity of common categories for biogas production plants, and it is an attempt towards finding a common classification for biogas plants.

\section{Acknowledgment}

This work was carried out within the Biogas Research Center (BRC). The BRC is funded by the Swedish Energy Agency, Linköping University, and participating organizations. We would like to thank Jenny Ivner, Mats Söderström and Maria Johansson for valuable comments and input. We also give special thanks to the workshop participants.

\section{References}

Avfall Sverige, 2014. Swedish Waste Management and Recycling association's handbook in landfilling [In Swedish]. Avfall Sverige, Malmö.

Bohn, I., Björnsson, L., Mattiasson, B., 2007. The energy balance in farm scale anaerobic digestion of crop residues at 11-37 C. Process Biochemistry 42, 57-64. 
Brancheforeningen for Biogas, 2014a. Centralized biogas plants [In Danish]

http://www.biogasbranchen.dk/om-biogas/faellesanlaeg (accessed March 2017)

Brancheforeningen for Biogas, 2014b. Farm biogas plants [In Danish].

http://www.biogasbranchen.dk/om-biogas/gaardanlaeg (accessed March 2017)

Drosg, B., 2015. Country Report Austria, IEA Bioenergy Task 37.

http://task37.ieabioenergy.com/country-reports.html (accessed March 2017)

Dumont, M., 2014. Country-update NL Angers: October 2014, IEA Bioenergy Task 37.

http://task37.ieabioenergy.com/country-reports.html (accessed March 2017)

Energigas Sverige, 2013. Swedish plants [In Swedish].

http://www.biogasportalen.se/BiogasISverigeOchVarlden/Anlaggningskarta\#lan=undefined

(accessed March 2017)

European Commission, 2007. Renewable Energy Road Map. Renewable energies in the 21st century: building a more sustainable future. European Commission, Brussels.

European Commission, 2009. Directive 2009/28/EC of the European Parliament and the Council of 23 April 2009 on the promotion of the use of energy from renewable sources and amending and subsequently repealing Directives 2001/77/EC and 2003/30/EC. European Commission, Brussels.

European Commission, 2010. Europe 2020: A Strategy for Smart, Sustainable and Inclusive Growth: Communication from the Commission. European Commission, Brussels.

European Commission, 2014. A Policy Framework for Climate and Energy in the period from 2020 to 2030. European Commission Brussels.

González-García, S., Bacenetti, J., Negri, M., Fiala, M., Arroja, L., 2013. Comparative environmental performance of three different annual energy crops for biogas production in Northern Italy. Journal of Cleaner Production 43, 71-83.

Holm-Nielsen, J.B., Al Seadi, T., Oleskowicz-Popiel, P., 2009. The future of anaerobic digestion and biogas utilization. Bioresource Technology 100, 5478-5484.

Huttunen, S., Manninen, K., Leskinen, P., 2014. Combining biogas LCA reviews with stakeholder interviews to analyse life cycle impacts at a practical level. Journal of Cleaner Production 80, 5-16.

IEA Bioenergy Task 37, 2014. Programme of work 2013-2015. http://task37.ieabioenergy.com/workprogram.html (accessed March 2017)

Igliński, B., Buczkowski, R., Cichosz, M., 2015. Biogas production in Poland-Current state, potential and perspectives. Renewable and Sustainable Energy Reviews 50, 686-695

Jorgensen, P.J., 2009. Biogas - green energy, 2 ed. Faculty of Agricultural Sciences, Aarhus University, Aarhus. 
Karlsson, N.P., Halila, F., Mattsson, M., Hoveskog, M., 2017. Success factors for agricultural biogas production in Sweden: A case study of business model innovation. Journal of Cleaner Production $142,2925-2934$.

Kaufmann, U., 2013. Swiss renewable energy statistics [In German], Bundesamt für Energie, BFE, Bern.

Linke, B., 2014. Country Report, Germany, IEA Bioenergy Task 37, http://task37.ieabioenergy.com/country-reports.html (accessed March 2017)

Murphy, J.D., 2012. Country Report Ireland, IEA Bioenergy Task 37,

http://task37.ieabioenergy.com/country-reports.html (accessed March 2017)

Naturvårdsverket, 2012. Biogas from waste products [In Swedish]. Naturvårdsverket, Stockholm.

NNFCC, 2014. Official Biogas Plant Map, http://www.biogas-info.co.uk/resources/biogas-map/ (accessed March 2017)

NSR, 2014. Landfill in development [In Swedish], http://www.nsr.se/Default.aspx?ID=818 (accessed March 2017)

Paulsson, J., Steinwig, C., 2013. Production and usage of biogas 2012 [In Swedish]. Swedish Energy Agency, Eskilstuna.

Prathibha Varkey, M., Hernandez, J.S., Schwenk, N., 2009. 6 techniques for creative problem solving. Physician Executive 35, 50.

Rintala, J., Pakarinen, O., 2012. Biogas in Finland - Country Report, IEA Bioenergy Task 37.

SP, 2014. Digestate [In Swedish].

http://www.sp.se/sv/index/services/certprod/certprodprofil/jord/biogodsel/Sidor/default.aspx (accessed March 2017)

Stambasky, J., Pluger, S., Deremince, B., Scheidl, S., de la Vega, N., Conton, M., 2016. Annual Statistical Report of the European Biogas Association. The European Biogas Association. Brussels.

Summers, I., White, D.E., 1976. Creativity techniques: Toward improvement of the decision process. Academy of Management Review 1, 99-108.

Söderåsens Bioenergi, 2017. Welcome to Söderåsens Bioenergy - at this site pure biogas is produced from pig manure and peas [In Swedish]. http://www.soderasensbioenergi.se/ (accessed October 2017)

Södra Hallands Kraft, 2014a. Biogas [In Swedish]. http://www.sodrahallandskraft.se/miljoe-ochenergieffektivisering/foernybar-energi-i-soedra-halland/biogas/ (accessed September 2014)

Södra Hallands Kraft, 2014b. Declaration of content [In Swedish]. http://www.sodrahallandskraft.se/media/7503/19__bruksanvisning_-_inneh_Ilsdeklaration.pdf (accessed September 2014) 
Södra Hallands Kraft, 2014c. How it works [In Swedish]. http://www.sodrahallandskraft.se/miljoeoch-energieffektivisering/foernybar-energi-i-soedra-halland/biogas/saa-haer-fungerar-det/ (accessed September 2014)

Sørheim, R., 2013. Country Report Norway, IEA Bioenergy Task 37.

http://task37.ieabioenergy.com/country-reports.html (accessed March 2017)

Theobald, O., Bastide, G., 2013. France Report, IEA Bioenergy Task 37.

http://task37.ieabioenergy.com/country-reports.html (accessed March 2017)

Uppsala Vatten, 2013. Environmental report [In Swedish].

http://www.mynewsdesk.com/se/uppsala-vatten-och-avfall-ab/documents/miljoerapport-

kungsaengsverket-2013-35357 (accessed March 2017)

Weiland, P., 2006. Biomass digestion in agriculture: a successful pathway for the energy production and waste treatment in Germany. Engineering in Life Sciences 6, 302-309. 


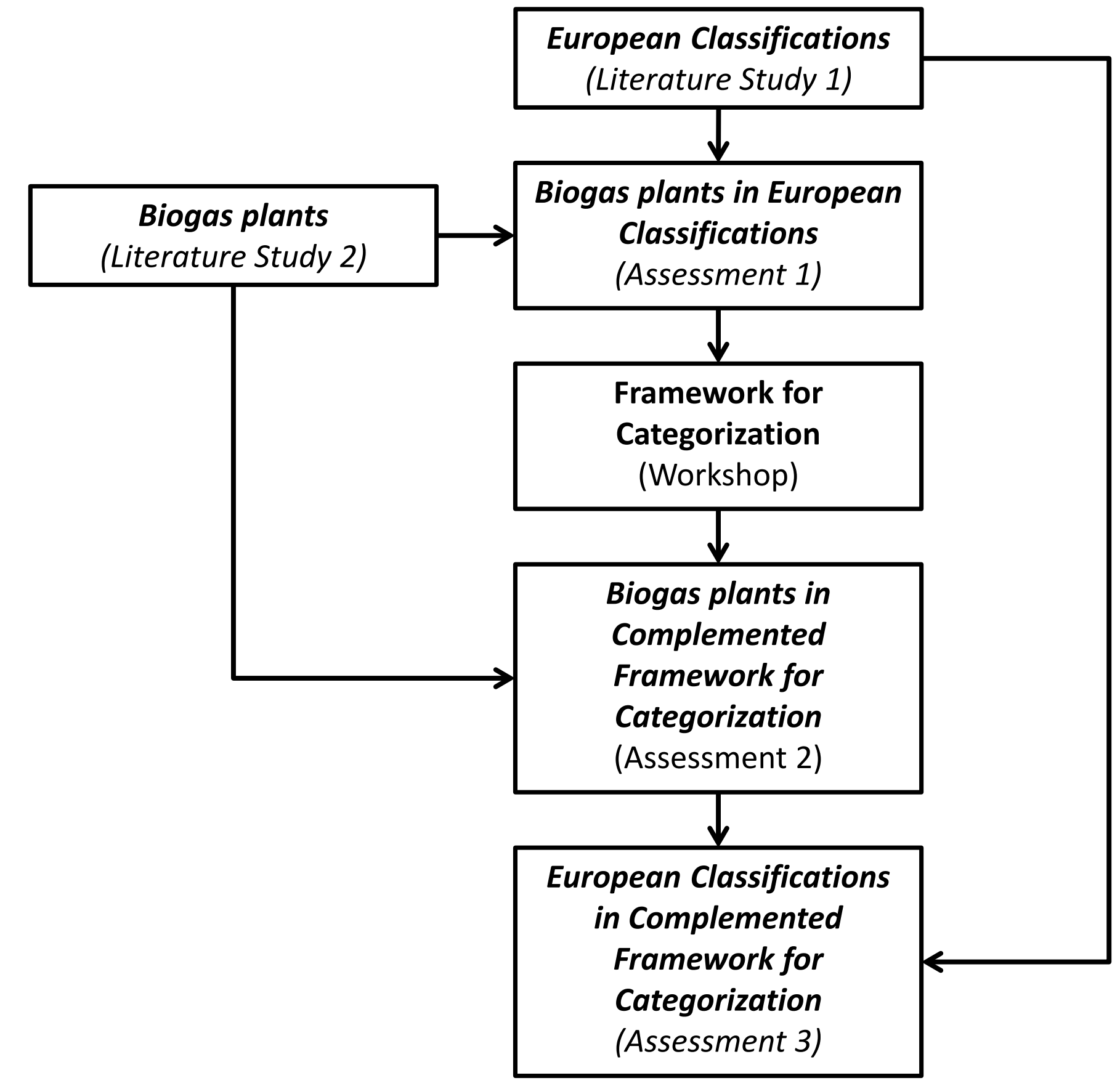




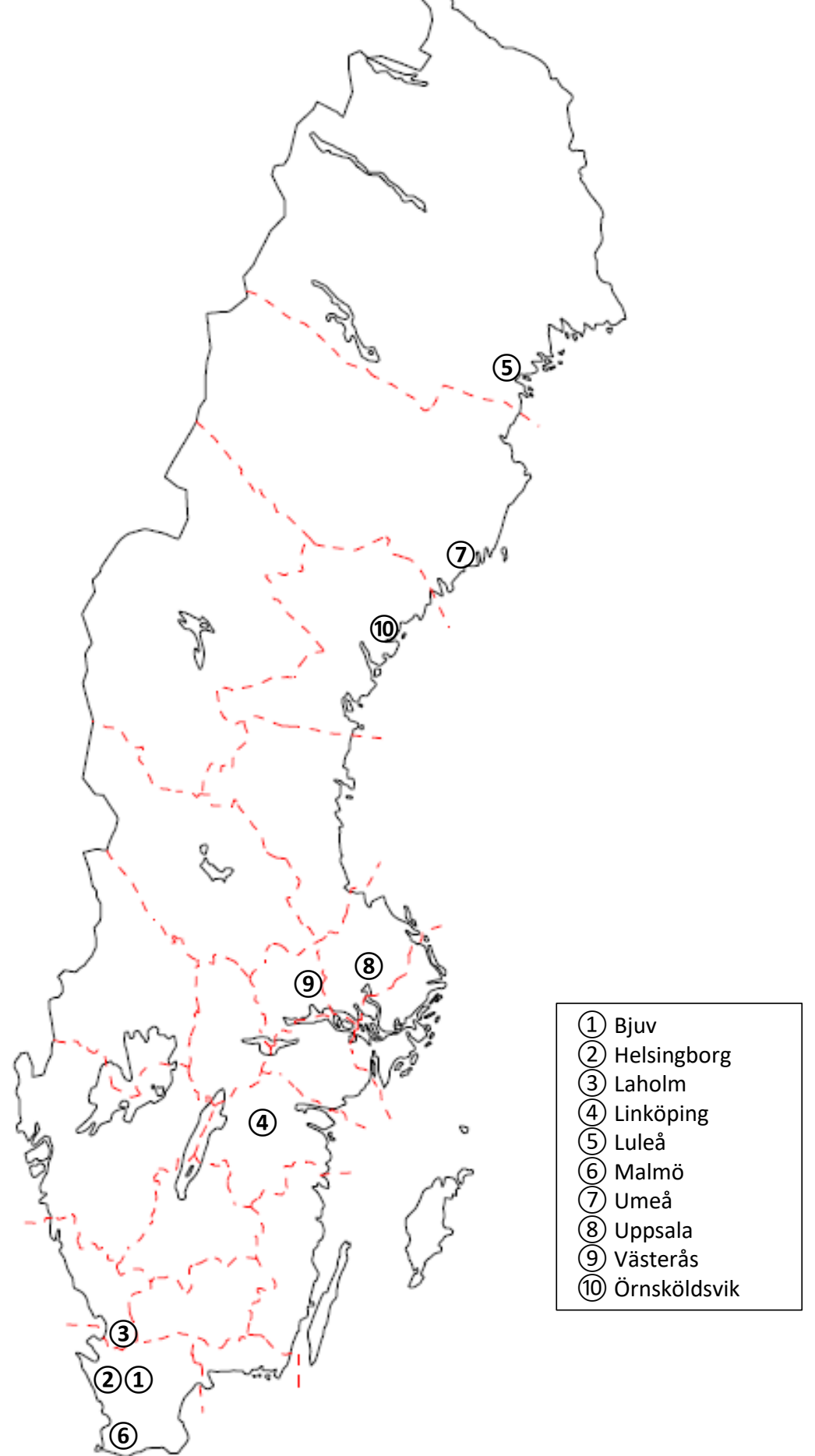


Figure 1. Working process in the study.

Figure 2. The plants studied. 
Table 1. Classifications of biogas plants in the European member countries in IEA Task 37.

\begin{tabular}{|c|c|c|c|c|c|c|c|c|c|c|}
\hline \multicolumn{4}{|c|}{ Countries with descriptions of the classifications } & \multicolumn{7}{|c|}{ Countries without descriptions of the classifications } \\
\hline Denmark $^{a}$ & Sweden $^{\mathrm{b}}$ & Switzerland $^{\mathrm{c}}$ & $U^{d}$ & Austria $^{\mathrm{e}}$ & Finland $^{f}$ & France $^{\mathrm{g}}$ & Germany $^{h}$ & Ireland $^{i}$ & Netherlands $\mathbf{s}^{j}$ & Norwayk \\
\hline & Landfill & Landfill & & Landfill & Landfill & Landfill & Landfill & Landfill & Landfill & Landfill \\
\hline $\begin{array}{l}\text { Centralized } \\
\text { Biogas }\end{array}$ & $\begin{array}{l}\text { Co- } \\
\text { digestion }\end{array}$ & $\begin{array}{l}\text { Commercial } \\
\text { /Industrial }\end{array}$ & Community & $A D$ & Co-digestion & Centralized & Biowaste & $\begin{array}{l}\text { Municipal } \\
\text { (Biowaste) }\end{array}$ & Co-digestion & Biowaste \\
\hline \multirow[t]{4}{*}{$\begin{array}{l}\text { Farm } \\
\text { Biogas }\end{array}$} & $\begin{array}{l}\text { Farm- } \\
\text { scale }\end{array}$ & Agriculture & Agricultural & & Farm & On-farm & Agriculture & Agriculture & $\begin{array}{l}\text { Other } \\
\text { Organic } \\
\text { Waste }\end{array}$ & Agriculture \\
\hline & WWTP & WWTP & $\begin{array}{l}\text { Water } \\
\text { Industry AD }\end{array}$ & $\begin{array}{l}\text { Sewage } \\
\text { Sludge }\end{array}$ & $\begin{array}{l}\text { Sewage, } \\
\text { Municipal }\end{array}$ & WWTP & $\begin{array}{l}\text { Sewage } \\
\text { Sludge }\end{array}$ & $\begin{array}{l}\text { Sewage } \\
\text { Sludge }\end{array}$ & $\begin{array}{l}\text { Sewage } \\
\text { Sludge }\end{array}$ & $\begin{array}{l}\text { Sewage } \\
\text { Sludge }\end{array}$ \\
\hline & Industrial & $\begin{array}{l}\text { Industrial } \\
\text { WW }\end{array}$ & Industrial & & $\begin{array}{l}\text { Sewage, } \\
\text { Industrial }\end{array}$ & Industrial & Industrial & Industrial & $\begin{array}{l}\text { Organic } \\
\text { Industrial } \\
\text { Waste }\end{array}$ & Industrial \\
\hline & & & & & & $\begin{array}{l}\text { Municipal } \\
\text { Solid Waste }\end{array}$ & & & & \\
\hline
\end{tabular}

a(Brancheforeningen for Biogas, 2014), b(Paulsson and von Bahr, 2014), c(Kaufmann, 2013), d(NNFCC, 2014), ${ }^{\mathrm{e}}($ Drosg, 2015), $\mathrm{f}($ Rintala and Pakarinen, 2012), $\mathrm{g}($ Theobald and Bastide, 2013), h(Linke, 2014), i((Murphy, 2012), j(Dumont, 2014), k(Sørheim, 2013) 
Table 2. The biogas plants studied inserted into the European classifications studied.

\begin{tabular}{|c|c|c|c|}
\hline Denmark & Sweden & Switzerland & United Kingdom \\
\hline $\begin{array}{l}\text { Farm } \\
\text { (5) } 6)\end{array}$ & $\begin{array}{l}\text { Farm-scale } \\
\text { (5) }\end{array}$ & $\begin{array}{l}\text { Agriculture } \\
\text { (5) (6) }\end{array}$ & Agricultural \\
\hline \multirow[t]{4}{*}{ Centralized } & $\begin{array}{l}\text { Co-digestion } \\
\text { (1)(3)(4)(6) (9) }\end{array}$ & $\begin{array}{l}\text { Commercial/Industrial } \\
\text { (4) }\end{array}$ & $\begin{array}{l}\text { Community } \\
\text { (1) (2)(3)(4)(5)(7) (9) }\end{array}$ \\
\hline & $\begin{array}{l}\text { Industrial } \\
\text { (7) (10) }\end{array}$ & $\begin{array}{c}\text { Industrial WW } \\
\text { (7) (10) }\end{array}$ & $\begin{array}{l}\text { Industrial } \\
\text { (7) (10) }\end{array}$ \\
\hline & $\begin{array}{l}\text { Landfill } \\
\text { (2) }\end{array}$ & $\begin{array}{l}\text { Landfill } \\
\text { (2) }\end{array}$ & Water industry AD 8) \\
\hline & $\begin{array}{l}\text { WWTP } \\
\text { (7) (8) (10) }\end{array}$ & $\begin{array}{l}\text { WWTP } \\
\text { (8) }\end{array}$ & \\
\hline
\end{tabular}

(1)Bjuv (2)Helsingborg (3)Laholm (4)Linköping (5)Luleå (6)Malmö (7)Umeå (8) Uppsala (9)Västerås (10) Örnsköldsvik 
Table 3. The Complemented Framework for Categorization

\begin{tabular}{|c|c|c|c|c|c|c|c|}
\hline Substrate & Organization & Biogas Use & Digestion & \multicolumn{2}{|c|}{ Localization } & Digestate & Capacity \\
\hline Manure & Municipality & $\begin{array}{l}\text { Vehicle } \\
\text { Fuel }\end{array}$ & $\begin{array}{l}\text { Mesophilica } \\
\left(15-45^{\circ} \mathrm{C}\right)\end{array}$ & $\begin{array}{l}\text { Main } \\
\text { Substrate } \\
\text { On-site }\end{array}$ & $\begin{array}{l}\text { Upgrading On- } \\
\text { site }\end{array}$ & $\begin{array}{l}\text { Certified } \\
\text { Fertilizer }\end{array}$ & $\begin{array}{l}\text { Small } \\
\left(<1,000 \mathrm{~m}^{3}\right)\end{array}$ \\
\hline $\begin{array}{l}\text { Industrial } \\
\text { Waste }\end{array}$ & Commercial & Electricity & $\begin{array}{l}\text { Thermophilica } \\
\left(40-65{ }^{\circ} \mathrm{C}\right)\end{array}$ & $\begin{array}{l}\text { Substrate } \\
\text { Pumped }\end{array}$ & $\begin{array}{l}\text { Gas Transported } \\
\text { by Vehicle }\end{array}$ & $\begin{array}{l}\text { Soil } \\
\text { Improvement }\end{array}$ & $\begin{array}{l}\text { Medium } \\
(1,000- \\
\left.10,000 \mathrm{~m}^{3}\right)\end{array}$ \\
\hline $\begin{array}{l}\text { Wastewater } \\
\text { Sludge }\end{array}$ & $\begin{array}{l}\text { Substrate } \\
\text { Owner }\end{array}$ & Heat & & $\begin{array}{l}\text { Substrate } \\
\text { Transported } \\
\text { by Vehicle }\end{array}$ & Local Gas Grid & $\begin{array}{l}\text { Uncertified } \\
\text { Fertilizer }\end{array}$ & $\begin{array}{l}\text { Large } \\
\left(>10,000 \mathrm{~m}^{3}\right)\end{array}$ \\
\hline MSW & $\begin{array}{l}\text { Shared } \\
\text { Ownership }\end{array}$ & $\begin{array}{l}\text { National } \\
\text { Gas Grid }\end{array}$ & & & National Gas Grid & & \\
\hline Fat & & $\begin{array}{l}\text { Internal } \\
\text { Use }\end{array}$ & & & Internal Use & & \\
\hline Crops & & & & & $\begin{array}{l}\text { Energy } \\
\text { Conversion for } \\
\text { External Use }\end{array}$ & & \\
\hline
\end{tabular}

à(Jorgensen, 2009) 
Table 4. The Complemented Framework for Categorization with the biogas plants studied inserted into it.

\begin{tabular}{|c|c|c|c|c|c|c|c|}
\hline Substrate & Organization & Biogas Use & $\begin{array}{l}\text { Digestion } \\
\text { Technology }\end{array}$ & \multicolumn{2}{|c|}{ Localization } & Digestate $^{a}$ & Capacitya \\
\hline $\begin{array}{l}\text { Manure } \\
\text { (1)(3)(5) }\end{array}$ & $\begin{array}{l}\text { Municipality } \\
\text { (2) } 89\end{array}$ & $\begin{array}{l}\text { Vehicle } \\
\text { Fuel } \\
\text { (4) } 89\end{array}$ & $\begin{array}{l}\text { Mesophilic } \\
\left(15-45^{\circ} \mathrm{C}\right) \\
\text { (1) } 3 \text { (4) } 6 \\
\text { (7) } 8 \text { (9) } 10\end{array}$ & $\begin{array}{l}\text { Main } \\
\text { Substrate } \\
\text { On-site } \\
\text { (1) } 2 \text { (5) } 6 \\
\text { (7) } 8 \text { (10) }\end{array}$ & $\begin{array}{l}\text { Upgrading } \\
\text { On-site } \\
\text { (1) } 89\end{array}$ & $\begin{array}{l}\text { Certified } \\
\text { Fertilizer } \\
\text { (1) (3) (4) } 6 \\
\text { (8) }\end{array}$ & $\begin{array}{l}\text { Small } \\
(<1,000 \\
\left.\mathrm{m}^{3}\right) \\
6\end{array}$ \\
\hline $\begin{array}{l}\text { Industrial } \\
\text { Waste } \\
\begin{array}{l}\text { (1) } 3 \text { (4) } 5 \\
\text { (6) } 7 \text { (10 }\end{array}\end{array}$ & $\begin{array}{l}\text { Commercial } \\
\text { (3) }\end{array}$ & $\begin{array}{l}\text { Electricity } \\
\text { (5) } 68 \\
108\end{array}$ & $\begin{array}{l}\text { Thermophilic } \\
\left(40-65^{\circ} \mathrm{C}\right) \\
5\end{array}$ & $\begin{array}{l}\text { Substrate } \\
\text { Pumped } \\
\text { (1) }\end{array}$ & $\begin{array}{l}\text { Gas } \\
\text { Transported } \\
\text { by Vehicle } \\
\text { (4) } 8 \text { (10) }\end{array}$ & $\begin{array}{l}\text { Soil } \\
\text { Improvement } \\
\text { (9) } 10\end{array}$ & $\begin{array}{l}\text { Medium } \\
(1,000- \\
\left.10,000 \mathrm{~m}^{3}\right) \\
1 \text { (3) } 5 \\
\text { (7) } 8\end{array}$ \\
\hline $\begin{array}{l}\text { Wastewater } \\
\text { Sludge } \\
\text { (7) } 810\end{array}$ & $\begin{array}{l}\text { Substrate } \\
\text { Owner } \\
\text { (5) } 610\end{array}$ & $\begin{array}{l}\text { Heat } \\
\text { (2) (10) }\end{array}$ & & $\begin{array}{l}\text { Substrate } \\
\text { Transported } \\
\text { by Vehicle } \\
\text { (1) } 3 \text { (3) } 5 \\
\text { (6) } 7 \text { ( } 9\end{array}$ & $\begin{array}{l}\text { Local Gas } \\
\text { Grid } \\
\text { (4) } 9\end{array}$ & $\begin{array}{l}\text { Uncertified } \\
\text { Fertilizer } \\
\text { (5) } 799\end{array}$ & $\begin{array}{l}\text { Large } \\
(>10,000 \\
\left.\mathrm{m}^{3}\right) \\
\text { (4) } 10\end{array}$ \\
\hline $\begin{array}{l}\text { MSW } \\
\text { (2) (4) } 9\end{array}$ & $\begin{array}{l}\text { Shared } \\
\text { Ownership } \\
\text { (1) } 7\end{array}$ & $\begin{array}{l}\text { National } \\
\text { Gas Grid } \\
\text { (1) } 3\end{array}$ & & & $\begin{array}{l}\text { National } \\
\text { Gas Grid } \\
\text { (1) 3 }\end{array}$ & & \\
\hline $\begin{array}{l}\text { Fat } \\
\text { (9) }\end{array}$ & & $\begin{array}{l}\text { Internal } \\
\text { Use } \\
\text { (5) } 67 \\
10\end{array}$ & & & $\begin{array}{l}\text { Internal Use } \\
\text { (5) } 67\end{array}$ & & \\
\hline $\begin{array}{l}\text { Crops } \\
\text { (9) }\end{array}$ & & & & & $\begin{array}{l}\text { Energy } \\
\text { Conversion } \\
\text { for External } \\
\text { Use } \\
\text { (2) }\end{array}$ & & \\
\hline
\end{tabular}

a Not applicable for Helsingborg (2) b(Jorgensen, 2009)

(1)Bjuv (2)Helsingborg (3)Laholm (4)Linköping (5)Luleå (6)Malmö (7)Umeå (8)Uppsala (9)Västerås (10) Örnsköldsvik 
Table 5. The European classifications incorporated into the Complemented Framework for Categorization.

\begin{tabular}{|c|c|c|c|c|c|c|c|}
\hline Substrate & Organization & Biogas & Digestion & \multicolumn{2}{|c|}{ Localization } & Digestate & Capacity \\
\hline $\begin{array}{l}\text { Manure } \\
\text { DEN, SWE, } \\
\text { SUI, UK }\end{array}$ & Municipality & $\begin{array}{l}\text { Vehicle } \\
\text { Fuel }\end{array}$ & $\begin{array}{l}\text { Mesophilica } \\
\left(15-45^{\circ} \mathrm{C}\right)\end{array}$ & $\begin{array}{c}\text { Main } \\
\text { Substrate } \\
\text { On-site } \\
\text { DEN, SWE, } \\
\text { UK }\end{array}$ & $\begin{array}{l}\text { Upgrading } \\
\text { On-site }\end{array}$ & $\begin{array}{l}\text { Certified } \\
\text { Fertilizer }\end{array}$ & $\begin{array}{c}\text { Small } \\
(<1,000 \\
\left.\mathrm{m}^{3}\right)\end{array}$ \\
\hline $\begin{array}{l}\text { Industrial } \\
\text { Waste } \\
\text { DEN, SWE, } \\
\text { SUI, UK }\end{array}$ & Commercial & $\begin{array}{c}\text { Electricity } \\
\text { DEN }\end{array}$ & $\begin{array}{l}\text { Thermophilic } \\
\left(40-65^{\circ} \mathrm{C}\right)\end{array}$ & $\begin{array}{l}\text { Substrate } \\
\text { Pumped }\end{array}$ & $\begin{array}{c}\text { Gas } \\
\text { Transported } \\
\text { by Vehicle }\end{array}$ & $\begin{array}{c}\text { Soil } \\
\text { Improvement }\end{array}$ & $\begin{array}{l}\text { Medium } \\
(1,000- \\
\left.10,000 \mathrm{~m}^{3}\right)\end{array}$ \\
\hline $\begin{array}{l}\text { Wastewater } \\
\text { Sludge } \\
\text { SWE, SUI, UK }\end{array}$ & $\begin{array}{c}\text { Substrate } \\
\text { Owner }\end{array}$ & $\begin{array}{l}\text { Heat } \\
\text { DEN }\end{array}$ & & $\begin{array}{l}\text { Substrate } \\
\text { Transported } \\
\text { by Vehicle }\end{array}$ & $\begin{array}{l}\text { Local Gas } \\
\text { Grid }\end{array}$ & $\begin{array}{l}\text { Uncertified } \\
\text { Fertilizer }\end{array}$ & $\begin{array}{c}\text { Large } \\
(>10,000 \\
\left.\mathrm{m}^{3}\right)\end{array}$ \\
\hline $\begin{array}{c}\text { MSW } \\
\text { DEN, SWE, } \\
\text { SUI, UK }\end{array}$ & $\begin{array}{c}\text { Shared } \\
\text { Ownership }\end{array}$ & $\begin{array}{l}\text { National } \\
\text { Gas Grid }\end{array}$ & & & $\begin{array}{l}\text { National } \\
\text { Gas Grid }\end{array}$ & & \\
\hline Fat & & $\begin{array}{l}\text { Internal } \\
\text { Use } \\
\text { DEN }\end{array}$ & & & $\begin{array}{l}\text { Internal Use } \\
\text { DEN, SUI }\end{array}$ & & \\
\hline $\begin{array}{c}\text { Crops } \\
\text { DEN, SWE, } \\
\text { UK }\end{array}$ & & & & & $\begin{array}{c}\text { Energy } \\
\text { Conversion } \\
\text { for External } \\
\text { Use } \\
\text { DEN }\end{array}$ & & \\
\hline
\end{tabular}

a(Jorgensen, 2009)

Denmark (DEN), Sweden (SWE), Switzerland (SUI) and United Kingdom (UK) 